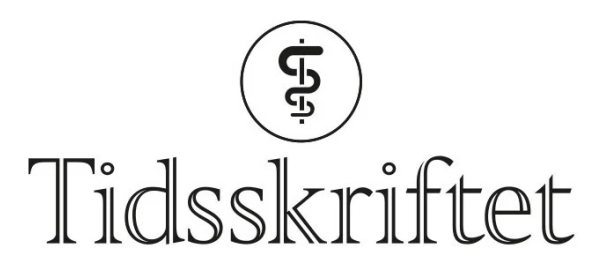

DEN NORSKE LEGEFORENING

\title{
Jakten på evidensen
}

\author{
LEGELIVET
}

INGRID HOKSTAD

ihokstad@gmail.com

Ingrid Hokstad er lege i spesialisering i medisinsk biokjemi ved Sykehuset Innlandet.

Ville du hyret inn en advokat som ikke hadde tilgang til Norges lover, eller en arkitekt som ikke hadde lest gjeldende byggtekniske forskrifter? Antagelig ikke. Likevel er det slik situasjonen er for mange leger: Vi har ikke nødvendigvis tilgang til den nyeste kunnskapen om sykdommene vi behandler.

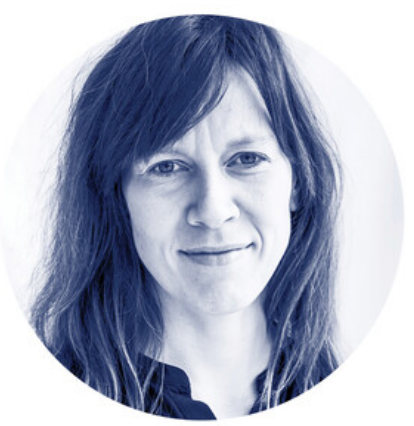

Som leger stiller vi oss ofte spørsmål om hvordan en sykdom kan behandles på best mulig måte, eller hvordan vi stiller en korrekt diagnose. Pasienten har kanskje en atypisk sykehistorie, og vi vil se om det finnes publiserte kasusstudier med lignende symptombilde. Flinke som vi er, søker vi derfor opp de nyeste artiklene om temaet i PubMed. Men som regel blir vi dessverre møtt av beskjeden om at «artikkelen er ikke tilgjengelig» (med mindre du punger ut hundrevis av kroner for å lese).

Den medisinske utviklingen går raskt. Lærebøkene fra medisinstudiet blir fort utdatert. God pasientbehandling forutsetter at klinikere er oppdatert på nye behandlinger og diagnosemetoder. Selvfølgelig er det ikke hensiktsmessig at hver enkelt lege skal forsøke å søke opp vitenskapelige publikasjoner hver gang hen skal behandle en pasient, stort sett finnes informasjonen vi trenger i retningslinjer og prosedyrer. Men retningslinjer kan ikke gi svar på alle komplekse og mangeartede problemstillinger. Dessuten tar det gjerne lang tid fra forskning utgis til ny kunnskap implementeres i praksis. Derfor er det essensielt at vi kan søke opp og lese nye studier når de blir publisert. 
I strategidokumenter fra helsemyndighetene finner vi rikelig med fagre ord om viktigheten av å kunne finne og anvende relevant forskning som en forutsetning for god pasientbehandling. Den nylig avgåtte regjeringen fastslo tidlig at et av deres hovedprosjekter var å «realisere kunnskapssamfunnet» og skrev følgende:

«Forskning er viktig for at helsetjenesten skal holde seg oppdatert innen den medisinske utviklingen og for å foreta kritiske vurderinger av etablerte og nye diagnostiske metoder, behandlingstilbud og teknologi, for arbeid med kvalitetsutvikling og pasientsikkerhet samt for å ivareta og veilede pasientene» (1).

Det høres jo flott ut, men betyr lite dersom all denne forskningen ikke er tilgjengelig, hvis infrastrukturen på arbeidsplassen hindrer oss i å ta denne kunnskapen i bruk.

«Det blir som å lcere opp båtmannskap i bruk av nye redningsbåter, for så å nekte rederiet å kjøpe inn disse båtene»

Diskrepansen mellom ord og handling er påfallende: I fjor valgte nemlig Helse- og omsorgsdepartementet å kutte ut tilgangen til en bred portefølje av medisinske tidsskrifter via Helsebiblioteket - for å spare 10 millioner (!) kroner. Bare de obligatoriske kursene i kunnskapsbasert praksis for sykehusenes LIS-leger koster jo langt mer enn dette. Hvis vi heller kunne bruke disse pengene på tilgang til artikler, hadde jeg gladelig ofret en kurstime til fordel for en YouTube-video om søketeknikk. Det blir som å lære opp båtmannskap i bruk av nye redningsbåter, for så å nekte rederiet å kjøpe inn disse båtene. Hvorfor skal man investere tid og penger på å lære opp folk til å finne og vurdere forskning de ikke kan lese?

Et annet aspekt ved dette er forskjellsbehandlingen mellom små og store helseforetak: Universitetssykehus har fortsatt tilgang til mange vitenskapelige tidsskrifter, mens mindre sykehus må klare seg med nærmest ingenting. Er det rettferdig overfor pasienter og deres behandlere? Har pasientene ute i distriktene enklere lidelser? Dette er ingen teoretisk diskusjon - det handler om den enkelte pasient som står der med en problemstilling vi ikke vet svaret på, og som trenger vår hjelp. Da er det utrolig frustrerende å føle at systemet hindrer oss i å yte den hjelpen vi prøver å gi.

Hva hadde pasientene sagt om de visste at vi ikke engang har tilgang til å lese de nyeste tidsskriftene innen eget fagfelt? Neste gang du hører en pasient klage på at hen ikke får tilgang på nye behandlinger eller diagnostiske metoder, er det kanskje ikke så rart. Vi som jobber i helsevesenet har trolig ikke hørt om det, skjønner du.

\section{LITTERATUR}

1. Regjeringen.no. Forskning i helseforetakene: organisering og nøkkeltall. https://www.regjeringen.no/no/tema/helse-og-omsorg/innsikt/helseforskning/innsikt/forskning-ihelseforetakene--organiserin/id585593/ Lest 22.9.2021.

Publisert: 22. oktober 2021. Tidsskr Nor Legeforen. DOI: 10.4045/tidsskr.21.0676

(C) Tidsskrift for Den norske legeforening 2023. Lastet ned fra tidsskriftet.no 26. april 2023. 